\title{
Identity and Self-Representation in the Francophone African Novel: Finding Henri Lopes in Le Lys et le flamboyant
}

Deena AMIRY

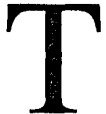

heories of self-representation and identity have been rigorously explored in Francophone African literature ever since the earliest waves of the bildungsroman.' The works of contemporary Congolese novelist Henri Lopes (1937-) provide an interesting perspective on the study of self-representation. Critics have gone to great lengths to comment on the autobiographical nature of Lopes' most recent novels and Lopes has given numerous interviews on the subject. ${ }^{2}$ Despite critics' tendencies to cite these interviews in their literary analyses, very little attention has been dedicated to the interview as a genre. ${ }^{3}$ I will dedicate this article to Henri Lopes' interviews and essays (Lopes' essays, like his interviews, focus primarily on himself) and their relationship to his fiction.

Postcolonial critics have highly polarized opinions regarding the use of facts about an author's life or other extra-textual information to interpret literary works. Proponents of this approach, such as Jean-Marc Moura, claim that grounding a text within its historical, political, or sociological context is crucial to interpreting a Francophone Literary work and distinguishing it from its Occidental counterpart. ${ }^{+}$Critics include Locha Mateso, who views the privileging of what he calls the "hors-texte" as inevitably detrimental to the text itself..$^{5}$

Cognizant of the dangers that Mateso exposes, I maintain that an examination of Lopes' texts will reveal a mimetic relationship between the 
image of Henri Lopes, the writer, and the artist figures of his most recent novel Le lys et le flamboyant (1997). Once established, this relationship will serve as a medium to re-evaluate the relevance of Lopes' interviews to contemporary literary criticism.

Raymond Jean's analysis of his interviews with twentieth-century poet Guillevec provides a starting point for my study of the interview as text. Jean examines the importance of both the author as a physical presence and of the utterances that the writer makes:

... [l]'importance grandissante accordée au corps, à la voix de l'artiste, à sa presence physique en général, modifie jusqu'aux processus habituels de lecture et de critique. II n'en reste pas moins vrai qu'en tant que genre "l'entretien-lecture" constitue en lui-même quelque chose d'inhabituel qui peut désorienter le lecteur davantage familiarisé avec les essays littéraires ou avec des entretiens traditionnels. Mais qu'un poète puisse s'exprimer instantanément, au fil du texte, voilà une chance rare à ne pas manquer et qui devrait largement compenser les inconvénients. ${ }^{6}$ Jean admits a certain unusual quality of the Guillevec interviews: they are neither literary criticism nor "traditional interviews." $\mathrm{He}$ envisions the "entretien-lecture" as a kind of immediate literature in which the writer's words go straight from the mouth to the page. At the end of his introduction, Jean mentions that there exist "disadvantages" to the interview process, yet unfortunately he never clarifies what these may be.

From Jean, I take the notion of the immediacy of the interview process. I believe a link can be derived between this genre and the epistolary novel's Richardsonian ideal of "writing to the moment." Writers of the letter try to give their prose a heightened sense of the present, attempting to bridge the gap between themselves and their respective correspondents. In the interview, it is as if the "moment is written." The interviewer publishes the author's responses, trying to capture the writer's sentiment and spirit at the moment of enunciation. Secondly, both epistolarity and interviews are based on an exchange of ideas between two or more parties. Neither the questions nor the responses occur in a vacuum, but rather depend upon the participants' immediate moods, attitudes, and preoccupations. Finally, just as addressers strive to eliminate the distance between themselves and the addressees, an interviewer publishes an interview, in part, to eliminate distance between the writer and the reader. Critics exemplify this idea when they utilize interviews in their articles: they are going to "the source," thereby eliminating the distance between their 
argument, the writer and the reader. On this topic Robert Root, who compiled a collection of unabridged interviews of several authors, writes:

I felt that the writers ought to be allowed to speak for themselves about the writing they had done and that readers ought to be able to read the finished pieces themselves in the context of their authors' comments.... Another justification, then, for publishing the interviews and articles along with the analysis is the opportunity it provides readers to go beyond my discussion of them. ${ }^{8}$

It is important to examine why Root believes that an interview allows a reader closer to the literary work, rather it draws the reader closer to the author. By valorizing this approach, Root clearly adheres to the notion that an author's ideas add to the discussion of the work, thereby making the interview an enriching experience. Root never prioritizes the author's words above the Text; he simply compares interviews to a critic's humble literary interpretation. Both attempt, but can equally fail, to decode or break down the text for the reader.

Thus, comparing the interview to epistolarity is useful in comprehending the immediacy of the genre, its focus on exchange, as well as its capacity to shrink the rift between author, subject, and reader. However, the comparison does not give a complete picture. Unlike epistolarity, which is necessarily a written genre, the published interview begins as a conversation. This specificity of the interview must be considered in order to attain a better understanding of the genre. In a preface to Off Stage Voices: Interview's with Modern French Dramatists, Robert Champigny writes: "By nature, interviews are closer to the theatre (logic of misunderstanding, comedy of errors) than to criticism."' Expanding upon Champigny's theatre analogy, I believe that interviews more precisely resemble a kind of improvisation act. They carry the same possibility of blunders and confusion. Moreover, interviews take place in a real space, like the stage of a theatre. For example, Raymond Jean goes so far as to define the room where his Guillevec interviews took place: "Les cinq entretiens ont eu lieu au domicile parisien du poète dans son bureau dont la fenêtre donne sur l'arrière du Val-de-Grace."10 This description bears a striking resemblance to theatrical stage directions. Detailing the boundaries of the interview space to this degree once again implies that the writer's physical presence is as important as the remarks he makes.

Therefore, characterizing the interview as a genre requires a circular analysis. We begin with the published work, a written document that strives in part to eliminate distance between the author and his text as well 
as between the author and the reader. Next, it is essential to step back and envision the interview as the conversation between the interviewer and the interviewee. Finally, a study of the interview must come full circle, forward again to the published document. Accepting that conversations risk miscommunication means that this same misinterpretation can find its way into the text. Hence, interviews can successfully bridge the gap between author, subject and reader; or interviews can, through such misinterpretation, thwart this objective.

As a result, when citing interviews to establish an argument, critics must use caution, for interviews can contain questionable material. On the other hand, when examined as a "moment written," they are often successful. When documented, writers' words have a potential artistic value, even if what they say is not necessarily factual or if they would not adhere to the statement made at a different period of time. The instant that the interview captures is quite possibly a significant moment that merits analysis as its own creation.

Before commencing an analysis of Lopes' interviews as they relate to the Le Lys et le flamboyant, a brief summary of the novel might be useful here. The work is narrator/filmmaker Victor-Augagneur Houang's written account of Kolélé, a Congolese singing legend. Not an author by profession, Victor writes the manuscript in preparation of the documentary film he plans to make about her life. Meanwhile, a certain Achel has already written a biography of the singer, entitled Kolélé. Victor's manuscript denounces Achel's for the liberties it takes in depicting certain aspects of Kolélé's life which are unverifiable in reality.

We can draw a parallel between the focus on Kolélé's biography and the way that journalists and literary critics have extended their interest beyond Lopes' work and demonstrated a fascination with his personal life. While Lopes had always been in the public eye as a politician, it was not until the publication of Le Chercheur d'Afriques in 1990 that a surge of interest in Lopes' life occurred. "Critics wanted to know whether the protagonist of the novel, André Leclerc, was simply a pen name for Henri Lopes. In short, they looked for answers about the novel in the author's own life. For example, interviewer Hélène Koné asks Lopes: " $\wedge$ propos de votre roman Le Chercheur d'Afriques, doit-on parler de romanautobiographique tout simplement?"'12 Here it appears that Koné is referring to Philippe Lejeune's famous distinction between an autobiographical novel and an autobiography, which he describes in "The Autobiographical Pact." Lejeune defines the autobiographical genre as a "[r]etrospective prose narrative written by a real person concerning his own existence, where the focus is his individual life, in particular the story 
of his personality." ${ }^{\prime 3}$ According to Lejeune, for a text to be an autobiography, strictly speaking, the author and the narrator must share the same name. In a situation where the narrator has a fictitious name, Lejeune insists that while the reader might see a resemblance between the author and the narrator, it can no longer be considered an autobiography. Rather the latter should more appropriately be deemed an "autobiographical novel."

Within the framework of her question, Koné does not accept the possibility that Le Chercheur could be pure fiction, as even the term "roman autobiographique" implies a certain tie between author and subject. On the contrary, she pushes the realm of the autobiography beyond Lejeune's definition. For Koné to postulate that Le Chercheur is an autobiography means that she willingly stretches Lejeune's definition to include a situation where the author and the narrator do not share the same name. Instead, physical resemblance becomes the principal criteria for an autobiography. ${ }^{14}$ Furthermore, by not including fiction as one of her options, Koné assumes that there must be similarities between Lopes and André Leclerc.

In response to Koné, Lopes rejects both categorioes: "c'est un roman, et il n'est pas autobiographique." ${ }^{15}$ Lopes does not even entertain the notion of a degree of resemblance between himself and Leclerc. Instead, his response implies a desire to focus on the novel while the critic's question suggests more of an interest in Lopes than in Le Chercheur:

Le Lys et le flamboyant represents Victor's desire to discover the truth behind artist Kolélé's identity, just as Lopes' interviewers would like to discuss his true identity. Victor frequently denies the literary nature of his text, and claims to be on more of a fact-finding mission. His work is a reaction against a fictitious intradiegetic novel, entitled Kolélé. He explains: "La logique aurait commandé d'intituler cet ouvrage Kolélé, puisque tel est le nom de mon héroïne. Mais j'ai voulu éviter toute confusion avec le Kolélé d'un certain Achel, paru il y a bientôt vingt ans chez un éphémère éditeur de Kinshasa." 16 Within the novel, there are three main artist figures: Victor, the filmmaker and makeshift writer; Kolélé, the singer whose life is the subject of the movie/manuscript; and Achel, the writer of Kolélé. In fact there is arguably a fourth artist, a writer who is only mentioned but never seen: a certain Marcia Wilkinson who translates Kolélé into English.

In his manuscript, Victor's goal is to tell the truth about Kolélé's life. According to him, Achel's version is primarily false. Victor reproves every part of $\Lambda$ chel's manuscript that cannot be validated in reality. For in- 
stance, Victor criticizes Achel's long psychoanalysis of Kolélé's decision to reuse her given name, Simone Fragonard. Achel claims that this choice is proof of a subconscious desire to recapture her father. In Victor's opinion, since no one can honestly penetrate another's thoughts, it is wrong to print such hypotheses under the guise of a biography. As someone who truly loved Kolélé, Victor believes that facts alone can do justice to her life. His methodology appears to be that real life should interest readers and spectators more than speculation or invention.

It is perhaps this desire for truth that leads Victor to seek out Kolélé's Tam-Tam interview (a newspaper and interview, which exist only in Lopes' novel). Afterall, what could more accurately represent Kolélé's life than her own words? Victor's wish to find and read the Tam-Tam interview as a means of learning more about Kolélé's identity mimics the reader's desire to examine a Lopes interview as a means of discovering him. In both cases, there exists the notion that "real life" is more interesting than fiction.

However, in both the novel and in life, evidence suggests that interviews are not always an effective way to learn about the artist. For example, in the Tam-Tam article, the interviewer appears more interested in Kolélé's political involvement than in her music. This offends Kolélé: "Vous me posez là des questions trop compliquées pour une artiste. J'avais espéré de votre part une interview sur mon métier, celui de chanteuse, or depuis le début de cet entretien vous m'entraînez dans des considerations d'ordre politique." 17 Kolélé's criticism is an excellent illustration of how interviews can turn into a series of miscommunications. In the essay "My Novels, My Characters, and Myself," Lopes writes of the conflation that bad readers make between himself and his characters: "Because superficial readers detect the tone of my voice in these characters, they believe they have discovered me. They forget that every real author is a liar." 8 When interviewers like Koné make this same mistake, one must question just how often interviews are successful in bridging the gap between author, subject and reader.

However, the fact that Victor includes an interview in his manuscript does not in and of itself prove that he relies upon the genre for its truthvalue. For example, as Victor wonders whether he should have done an official interview of Kolélé, he debates whether or not it would have served any purpose:

Encore qu'il ne soit pas sûr qu'une interview serrée d'elle m'eut permis de percer les mystères qu'elle entretenait avec un brin de coquetterie. Et quand elle eut consenti à s'exprimer, eutce été pour livrer la vérité ou pour la dissimuler? Mais a-t-on 
besoin de tout expliquer? La réalité n'est-elle pas tout à la fois l'ombre et la lumière, l'une à l'Autre soudées. ${ }^{19}$

Victor doubts the authenticity of the interview process and fundamentally questions our capacity to grasp reality. In essence, Victor refutes a reader's assumptions about the truth of the interview process. Furthermore, in the epilogue, while grappling with the notion of fiction versus reality, Victor concludes that "[l]e romancier pense n'avoir puisé que dans ses rêves, quand il a réinventé la vie ou prophétise le reel."20 According to Victor, fiction is more real than we imagine whereas interviews are probably more fictitious.

Yet, in spite of the questionable reliability of the interview, the medium still holds a value within the novel Le Lys et le Flamboyant. Even though Victor questions the authenticity of an interview with Kolélé, he still includes the one from Tam-Tam in his story. This fact proves that while Victor might not entirely adhere to the practice, it maintains a certain worth for him, as it does for Lopes. Le Lys is Lopes' only first person narrative where the narrator is not the primary protagonist. Furthermore, since most of Lopes' novels are first-person narratives, it is rare that the protagonist would not have a venue to express his or her own voice. In Le Lys, ironically it is the singer who has no voice. Her story has been told by Achel and translated by Wilkinson ${ }^{21}$ and thus exists in multiple languages without ever revealing the singer's own words. Thus, given Lopes' tendency for a fusion between narrator and protagonist and Victor's mission to reveal the true Kolélé, it is no surprise that, although Victor's view of the interviews is at best ambivalent, he would still include it in his narrative. Furthermore, as a filmmaker rather than a writer, Victor has little to lose by including the interview in his novel. He repeatedly insists that he is not concerned with what is "literary," as a writer would be. Instead, the interview blends well with his desire to create a documentary film. Because interviews cross over genres (they can be written or filmed), the inclusion of the Tam Tam article creates the feel of a documentary film within the framework of the novel, while conveniently giving the protagonist a voice.

Parallel to the importance of hearing the artist's voice is Lopes' inclusion of himself as a character in Le Lys et le flamboyant. As the reader learns on the first page of the novel, $\Lambda$ chel is actually a pseudonym for Henri Lopes, "la transcription phonétique de ses initiales." 22 Not only is Lopes/Achel the author figure who writes Kolélé, but he was also one of Victor's childhood schoolmates. (For simplification, when I refer to the intradiegetic character Henri Lopes, I will use the name "Achel" even though Victor only refers to him as such on the first page, otherwise he 
calls him Lopes. While somewhat artificial, this designation will alleviate the need for the wordy distinctions of the intradiegetic character Henri Lopes and the extradiegetic author Henri Lopes). In fact, Victor mocks Achel at several points in the novel. For instance, he reveals that Achel had difficulty accepting his métis identity as a child, demonstrated by his desire to always play the cowboy in a game of cowboys and Indians. ${ }^{23}$ Furthermore, Victor divulges a lie in Achel's manuscript. Achel would have the reader believe that he grew up in the poorest of neighborhoods, when Victor knows for a fact that it is not true:

Ainsi peut-il se poser en nègre authentique qui aurait subi les humiliations du régime de l'indigenat. Comme s'il était nécessaire de recourir à de telles supercheries pour affirmer sa congolité. ${ }^{24}$

Whether or not Achel/Henri Lopes chose the cowboy over the Indian, or whether he lived in Poto-Poto as opposed to a more wealthy métis community, the reader cannot decide based on the information provided by the novel. Is Victor telling the truth or is Achel? In either case, it only adds to the extradiegetic reader's confusion as to the question: who is Henri Lopes? It appears that this masquerade is Lopes' response to the interviewers and readers who think that all of his main characters are purely autobiographical, because even when Lopes himself is a character in the novel, it is not necessarily $\mathrm{him}$.

On the other hand, at a later moment in the novel, Lopes would seem to lend credence to past comparisons of himself and the protagonist of $L e$ Chercheur d' Afriques, André Leclerc. While visiting Brussels, Victor spots someone he thinks to be $\Lambda$ chel on the street.

-Je ne me trompe pas, c'est bien Henri Lopes? ai-je bégayé, en lui tendant une main qu'il a considérée un instant avant de la serer.

-Non, monsieur, mais ce n'est pas grave....

Effectivement, ce n'était pas la voix d'Henri Lopes.

-Ce n'est pas grave, monsieur. Permettez que je me présente: André Leclerc...

Hormis les yeux verts, c'était pourtant la copie de la silhouette du visage de Lopes... ${ }^{25}$

Victor's mistaking André for $\Lambda$ chel would seem to further the notion of a physical resemblance between character and author. Later in their conversation, as Leclerc describes his connection to the Lopes family, there is even a hint that $A c h e l$ and he might share the same father. Supposing a genetic link between $A c h e l$ and Leclerc is either the ultimate affirma- 
tion of a connection between author and subject or the author's way of poking fun at the many resemblance theories postulated by critics. The answer appears to be the latter because subsequent elements of the conversation reveal that André Leclerc whom Victor meets in Brussels is not even the Leclerc of Le Chercheur d'Afriques. In Le Chercheur, André's father was French, not Belgian, and André lived in France, not Belgium. Furthermore, Le Chercheur ends with the adult protagonist's return to Africa, whereas the Leclerc in Le Lys has not been to his homeland since adolescence. Thus, Achel for Henri Lopes might very well resemble André Leclerc, but it is an André unknown to the reader. Lastly, it is significant to note that Achel and Leclerc, while capable of passing for identical twins (minus the eyecolor), do not share the same voice. Given Lopes' tendency to experiment with genres and language combined with the limited nature of physical descriptions in his works, voice is a more significant marker of resemblance or difference than appearance. Therefore, instead of envisioning a situation of a few characters that are actually one and the same, we must picture many characters who may resemble one another, but who are in fact distinct because their voices do not match. Lopes creates two Leclercs, but each tells a distinct story; similarly his "Achel" or Lopes character writes a different story than he does: Kolélé.

In addition, by examining the Achel character, we can discern both his distinction from Lopes and his fictitious nature. For example, the insinuation that Andre and Achel share the same father does not draw Andre closer to the "real" world, but instead sends Achel farther into an imaginary one. Anyone who reads Lopes' interviews or his commentary "My Novels, My Characters, and Myself" knows that he is the son of two métis parents, and unlike André, does not have a colonial father. Therefore, implying that Achel shares the same father with André only clarifies further that the Henri Lopes of Le Lys et le flamboyant is almost as illusory as the other characters in the novel. Even when they share the same name, Lopes goes through efforts to confuse fiction with reality. This diversion takes the attention off the way in which Lopes' life and experiences have influenced his novels, instead of demonstrating the author's willingness to play with his identity in fiction.

Multiple characters, personas and identities dominate Lopes' fiction. We no longer simply ask "who is Henri Lopes?" Several other inquiries are now raised. Who is André Leclerc? Who did Victor meet in Brussels? While he is not the character of Le Chercheur, he has green eyes just like the other André. Does the real André of Le Chercheur match the image of Achel? Le Lys only confirms that André Leclerc from Brussels does. The 
reader is no farther along in the quest to find out if André Leclerc from Le Chercheur is the incarnation of Henri Lopes. Instead, a new character is introduced, and the lines between fiction and reality remain muddled.

But whether imaginary or real, autobiographical or not, Lopes' incorporation of himself into Le Lys illustrates the importance that he places upon his name in his work. By including himself in the list of characters, Lopes wants the focus to be on him. In this case, the author is not simply "hors-texte." On the contrary, by consulting Lopes' interviews regarding his biography, the reader learns that the depiction he provides of the Henri character is primarily fictitious: he is not the child of a colonial father, and he never wrote a manuscript entitled Kolélé. Only by reading about Lopes, the artist, can the reader find his way through one of Lopes' favorite games, the confusion of fiction and reality. In an interview about Le Lys, Lopes admits that tricking the reader is one of his intentions: ". . . il y a un autre jeu: le désir de troubler, de perdre le lecteur avec deux autres réalités, celle de la fiction et celle de l'histoire."26 Interviews are important when investigating Lopes' work because of his willingness to play at the boundary between the real and the imaginary. Lopes pushes the reader to verify history through extratextual means because his version of the facts is at times intertwined with fiction.

To conclude, artist figures Kolélé and Henri Lopes possess an element in common insofar as their portraits are incomplete. In Le Lys ef le flamboyant, Victor's reluctance to interpret Kolélé's words or actions leads him to paint a limited picture of her. While the reader has several media through which to discover Lopes (interviews, essays and Le Lvs), each seems to provide a conflicting image of the author. I believe this is all Lopes' intention: he wants the reader to question what he writes. If few certainties are revealed about his characters, it is because the reader is responsible for "writing" the text in the way he decides and for "drawing" the portraits of the artists himself. Similarly, if Lopes includes his own name in a novel, it is because he wants the reader to ask about him, to question him. The author is relevant in this case because Lopes wishes it so and not because an author's life is always pertinent to his work. Literary criticism, such as Mateso's, should allow for exceptions. It should recognize that the focus on an author could stem from that same author's desire to be emphasized. It should also take into consideration an author, like Lopes, whose attraction to describing artist figures includes a fascination, perhaps a narcissistic one, with depicting himself. 


\section{Notes}

1. Examples of autobiographies and autobiographical novels include Oyono: Une Vie de Boy, Laye: L'Enfant noir, Kane: L'Aventure ambiguë, Dadié: Un Nègre à Paris. Without a doubt, Jacques Chevrier has written the most renowned critical analysis of autobiography and selfrepresentation.

2. See bibliography.

3. For example, Koffi Anyinefa's article entitled "Postcolonial Postmodernity in Henri Lopes' Le pleurer-rire" cites a Lopes interview in order to comment on the political nature of the novel.

4. Jean-Marc Moura, Littératures francophones et théories postcoloniales, (Paris: Presses Universitaires de France, 1999) 7.

5. Locha Mateso, La Littérature africaine et sa critique, (Paris: Karthala, 1986) 153.

6. Jacques Lardoux, Humour-Terraqué/Entretiens-Lectures, Saint(Denis: Presses Universitaires de Vincennes, 1997) 8.

7. Jean never defines what he understands to be a "traditional interview." I interpret his statement to mean interviews in all fields where the primary goal is to learn a few facts about the interviewee's life or work. This can be contrasted with the "entretien-lecture," a published interview with an author whose power as a storyteller transcends writing to include responses to questions of an interview.

8. Robert L. Root, Jr., Working at Writing, Columnists and Critics Composing, Preface (Edwardsville: Southern Illinois UP, 1991) xi.

9. Bettina Knapp, Off-Stage Voices: Interviews with Modern French Dramatists, (Troy, N.Y.: Whitston Pub. Co., 1975) iii.

10. Lardoux 11.

11. Note that not one of Lopes' interviews occurred before 1990 even though Tribaliques won the "Grand Prix de la littérature de l'Afrique noire" in 1972 and Le Pleurer-Rire received excellent reviews (see bibliography for references). "The protagonist of Le Chercheur d'Afriques, André Leclerc, is métis like the author. The reader can infer that it was the métissage question that fueled these interviews. In fact, the titles of the interviews support this theory. Critics have asked the question: how much of Henri Lopes is in André Leclerc?

12. Hélène Koné, "Tout métissage est un acte enrichissant," Fraternité-Matin 10 Nov. 1992, 10.

13. Philippe Lejeune, On Autobiography, (Minneapolis: U of Minnesota P, 1989) 4. 
14. One could argue that Leclerc's Congolese origins beg for the comparison. But aside from Le Pleurer-rire, which took place in an imaginary land, all of Lopes' novels have Congolese protagonists, and yet the novels' autobiographical nature was never presupposed. For this reason, I believe that only the métissage trait leads Koné to his conclusion.

15. Koné 10.

16. Lopes, Le Lys et le flamboyant 7.

17. Lopes, Le Lys et le flamboyant 400.

18. Lopes, "My Novels, My Characters, and Myself," African Urban Quarterly (1993) 86.

19. Lopes, Le Lys et le Flamboyant 373.

20. Lopes, Le Lys et le flamboyant 429.

21. The notion of translation, while secondary to my analysis, is still a phenomenon worth noting. Why does Lopes include Wilkinson's translation? What is the benefit or significance to the reader to mention that Kolélé was translated into English? I believe that it represents the state of affairs of the transmission of Francophone novels today. As stated in the first line of the prologue, Achel's novel Kolélé was published by an unknown and now out of business African publishing house. As is the case of many contemporary African novels, only as they are published abroad, and in this case translated, do they become known and read.

22. Lopes, Le Lys et le flamboyant 7.

23. Lopes, Le Lys et le flamboyant 136.

24. Lopes, Le Lys et le flamboyant 133.

25. Lopes, Le Lys et le flamboyant 312.

26. Boniface Mongo-Mboussa, 67. Notice that I have just used an excerpt from a Lopes interview to further my argument, thus placing myself amongst the critics that I talk about who do so. 


\section{Works Cited}

Anyinefa, Koffi. "Postcolonial Postmodernity in Henry Lopes' Le PleurerRire." Research in African Literatures 29 (1998 Fall): 8-20.

Knapp, Bettina. Off-Stage Voices: Interview's with Modern French Dramatists. Troy, N.Y.: Whitston Publishing Company, 1975.

Lardoux, Jaques. Humour-Terraqué/Entretiens-Lectures. Saint-Denis: Presses Universitaires de Vincennes, 1997.

Lejeune, Philippe. On Autobiography. Minneapolis: University of Minnesota Press, 1989.

Mateso, Locha. La Littérature africaine et sa critique. Paris: Karthala, 1986.

Moura, Jean-Marc. Littératures francophones et théorie postcoloniale. Paris: Presses Universitaires de France, 1999.

Root, Robert. Working at Writing, Columnists and Critics Composing. Edwardsville: Southem Illinois University Press, 1991.

\section{Primary Sources}

Lopes, Henri. Le Chercheur d'Afriques. Paris: Seuil, 1990.

—. "Une vie en un jour: Henri Lopes." Jeune Afrique. [Tunis] 7 July 1993.

- Le Lys et le flamboyant. Paris: Seuil, 1997.

-. "My Novels, My Characters, and Myself." Research in African Literatures 24 (1993 Spring): 81-86.

- La Nouvelle Romance. Yaoundé: Editions Clé, 1976.

—. Le Pleurer-Rire. Paris: Présence Africaine, 1982.

- Sans Tam-Tam. Yaoundé: Editions Clé, 1977.

—. Tribaliques. Yaoundé: Editions Clé, 1972. 


\section{Lopes Interviews}

Koné, Hélène. "Tout métissage est un acte enrichissant." Fraternité-Matin [Paris] 10 Nov. 1992: 10.

Kouediatouka, Folly. "Henri Lopes, le Chercheur d'Afriques." Le Soleil [Congo] Mar. 1991: 16.

Mérand, P. "Qui êtes-vous Henri Lopes?" Sepia 3 (1990): 5-8.

Milandou, M. "Henri Lopes: Un Romancier qui s'affirme." Le Fanion 8 (1990): 41.

Mongo-Mboussa, Boniface. "Entretien: Henri Lopes." Africultures [Paris] Nov. 1997: 65-71.

Rolland, Dominique. "D'Une Rive à l'autre: Entretien avec Henri Lopes." Diagonales 23 (1992): 3-4. 